\title{
Sudden Cardiac Death: Exploring the Limits of Our Knowledge
}

\author{
ROBERT J. MYERBURG, M.D. \\ From the Division of Cardiology, University of Miami School of Medicine, Miami, Florida
}

\begin{abstract}
Sudden Cardiac Death. Despite progress in epidemiology, clinical profiling, and interventions, sudden cardiac death remains a major clinical and public health problem. There remain important unresolved issues that are challenges for future progress. Among these are a better understanding of the magnitude of the problem and methods of profiling risk for individuals, the etiology and mechanisms of cardiac arrest in individuals with and without previously identified structural heart disease, clinical strategies for primary and secondary prevention of sudden cardiac death, and further development of community programs for improving cardiac arrest survival in the out-ofhospital environment. Each of these areas of endeavor and potential progress are reviewed and discussed. (J Cardiovasc Electrophysiol, Vol. 12, pp. 369-381, March 2001)
\end{abstract}

implantable defibrillators, out-of-hospital cardiac arrest, automated external defibrillators, risk factors, genetics

\section{Introduction}

The second half of the twentieth century was a watershed of progress in the medical sciences. Among the successes in the various disciplines of cardiovascular medicine was the evolution of a knowledge base for understanding causes and mechanisms of sudden cardiac death (SCD) and the development of clinical strategies for intervention. Beginning with little more than a general appreciation of an association between arteriosclerotic cardiovascular disease and SCD in the middle part of the century, ${ }^{1-3}$ a series of cognitive and technological advances followed upon one another, leading to meaningful insights and intervention strategies by the end of the century. With the dawn of the twenty-first century, the term "prevention of SCD" has begun to take on more than theoretical meaning.

Despite the series of successes, there still remain

Dr. Myerburg is funded in part by the Louis Lemberg Chair in Cardiology and the American Heart Association Chair in Cardiovascular Research at the University of Miami, Miami, Florida, and by Grant HL21735 from the National Heart, Lung, and Blood Institute, National Institutes of Health.

Address for correspondence: Robert J. Myerburg, M.D., Division of Cardiology, University of Miami School of Medicine, P.O. Box 016960, Miami, FL 33101. Fax: 305-585-7085; E-mail: rmyerbur@med.miami.edu

Manuscript received 9 November 2000; Accepted for publication 7 December 2000. important unresolved issues. The limits of the progress achieved define the challenges that remain for the future. These can by analyzed in the context of new insights required from the underlying basic and clinical sciences, the strategies needed for further progress in prevention, and the identification of reasonable expectations for improving outcomes.

The challenges begin with a more precise definition of the incidence of SCD and move to epidemiologic strategies that will predict fatal arrhythmic events more precisely. Beyond these, the development of better treatment strategies for individuals at risk must be sought, as well as more comprehensive and effective community intervention systems. New paradigms of predicting risks will have to integrate the various disciplines and interventions that may lead to reductions in the risk of $S C D$, combining both clinical strategies and community-based actions. Undoubtedly, progress will be incremental and cumulative; it is unrealistic to consider that a single strategic approach will have a meaningful impact on the complexities of SCD.

\section{Epidemiology of SCD: Population and Clinical Perspectives}

The magnitude of SCD as a public heath problem is self-evident, but the precise incidence remains uncertain. For more than 20 years, SCD has been stated to have an incidence of 300,000 deaths annually in the United States, with other estimates ranging from as low as 


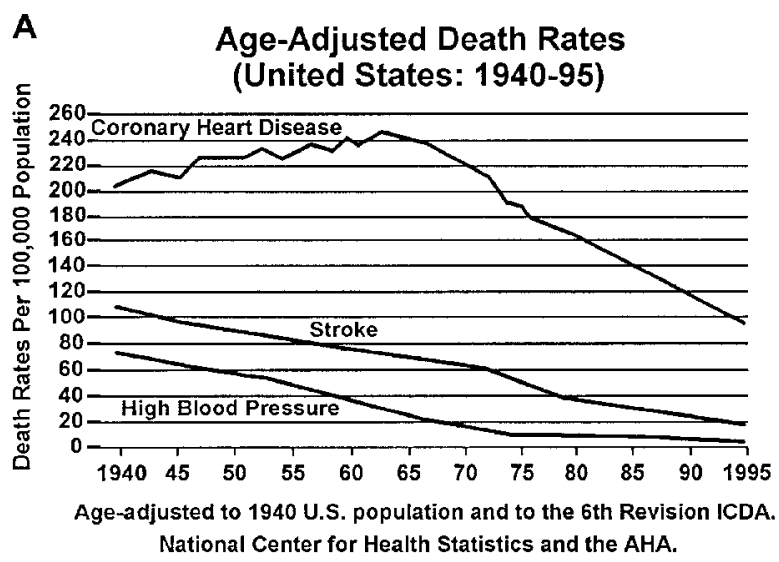

[FROM: Lewis RP; JACC 2000]

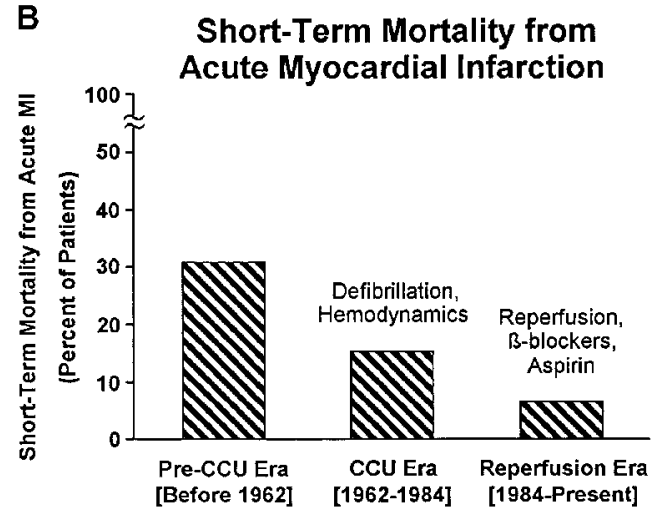

[FROM: Braunwald E; NEJM 1997]

Figure 1. Factors influencing estimate of the public health burden of sudden cardiac death. (A) Age-adjusted death rates from coronary heart disease, stroke, and high blood pressure, from 1940 to 1995. (Modified with permission from the American Journal of Cardiology [Journal of the American College of Cardiology], 2000;35:1061-1066). Decreasing age-adjusted risk does not inherently provide information on incidence or prevalence. (B) Estimates of the reduction in short-term mortality due to acute myocardial infarction during the second half of the twentieth century. Short-term mortality benefit results in increased population of survivors with chronic ischemic heart disease (Modified with permission from Braunwald E: Cardiovascular medicine at the turn of the millennium: Triumphs, concerns, and opportunities. N Engl J Med 1997;337:1360-1369. Copyright $(1) 1997$ Massachusetts Medical Society. All rights reserved.)

250,000 to 400,000 or more. ${ }^{4-8}$ This figure of 300,000 deaths accounts for an average of 1 to 2 deaths per 1,000 adults over the age of 35 per year and represents $50 \%$ of all heart-related deaths. ${ }^{8,9}$ Although the $50 \%$ proportion seems to hold up from a number of sources of data, the estimate of 300,000 SCDs per year is a derived figure, based on an assumption of 600,000 cardiovascular deaths per year in the mid-1970s. Although much has changed in the population substrate and interventional capabilities in cardiovascular diseases during the past 25 years, the estimates that formed the basis for the 300,000 SCDs annually have remained unchallenged.

An example of how changing clinical and epidemiologic patterns can influence SCD risk without being immediately apparent is shown in Figure 1. The decrease in age-adjusted risk of coronary heart disease death from the 1940s to 1995 (Fig. 1A) has been applauded as a statement of medical and public health progress. ${ }^{10}$ During the same period of time, there was a marked reduction in early mortality from acute myocardial infarction, initially thought to be related to the development of the coronary care unit and its effect on electrical and, to a more limited extent, mechanical deaths, and recently by more advanced therapies ${ }^{11,12}$ (Fig. 1B). The interaction between these two sources of data is complex. The age-adjusted risk curve expresses the fact that deaths from cardiovascular disease are occurring at older ages; it does not inherently state that the prevalence of heart disease or absolute numbers of death have changed. In addition, the short-term acute myocardial infarction mortality experience infers the establishment of a population of survivors who entered the pool of aging patients with cardiovascular disease. These factors combine with the general growth of the older population pool, because of increased birth rates during the middle part of the cen- tury. These several observations come together to suggest that, in an aging population with a lower short-term morality rate and a shifting age-adjusted risk, there is likely a growing population of patients at risk for various cardiovascular events. ${ }^{12}$ The events include the development of heart failure and the risk of SCD. Finally, the 300,000 figure does not factor in the suggestion that there are now estimated to be 750,000 cardiovascular deaths annually. ${ }^{12}$ In the absence of a properly designed survey that would allow a direct measure of SCD rates, the actual numerical magnitude of the risk of SCD remains speculative.

The magnitude of the risk of SCD is both age and cause related (Fig. 2), and these two factors interact. The general assumption of a risk of $0.1 \%$ to $0.2 \%$ per year among the population aged 35 and older is an average figure for patients across that age range. Among that segment of the general population, however, the risk of SCD is strongly age related, with the most marked increase in risk between the ages of 40 to 65 years. ${ }^{8}$ In that segment of the population, coronary artery disease is by far the most common cause of SCD (Fig. 3), accounting for approximately $80 \%$ of all SCDs. The collective cardiomyopathies, dominated by the dilated cardiomyopathies, account for another $10 \%$ to $15 \%$. Once coronary heart disease or cardiomyopathies are in advanced stages, they dominate and largely neutralize the agerelated component of SCD risk. Among patients with advanced structural heart disease, silent or recognized, it is the extent of disease rather than the age that determines risk; therefore, age-related risk curves tend to blunt in that subgroup of the population (Fig. 2).

At the other end of the age spectrum, adolescents and young adults (ages 10 to 30), the order of magnitude of SCD risk is about 1/100th that of the general adult 


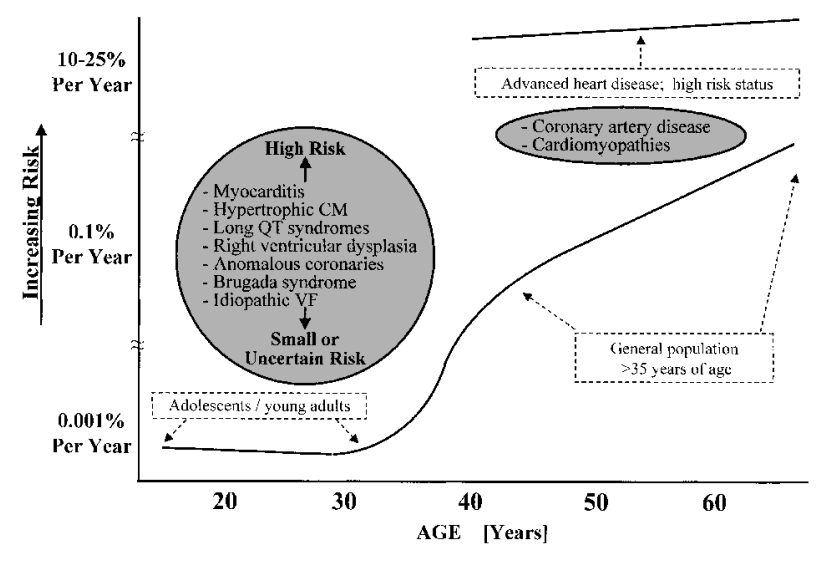

Figure 2. Age-related risk of sudden cardiac death, with influence of preexisting heart disease on magnitude of risk in middle-aged and older adults. The prevalent etiologies are a function of age. See text for details. (Modified with permission from Myerburg RJ, Castellanos A: Cardiac arrest and sudden cardiac death. In Braunwald E, ed: Heart Disease: A Textbook of Cardiovascular Medicine. Sixth Edition. WB Saunders, Philadelphia, 2001, pp. 890-931.)

population ( 1 per 100,000 individuals annually), and there appears to be a modest inverse age relationship, with the adolescent group having a higher mortality risk than young adults. It is likely that the risk of lethal arrhythmia in the genetically controlled disorders tend to express more commonly in the adolescent years. ${ }^{13}$ This is particularly evident for hypertrophic cardiomyopathy. ${ }^{14}$

The group of disorders responsible for SCD in the adolescent and young adult group is distinctly different from those in the middle-aged to elderly group. Coronary atherosclerosis is an uncommon cause, with myocarditis, hypertrophic cardiomyopathy, long QT syndromes, right ventricular dysplasia, anomalous

$\triangleright$ CORONARY HEART DISEASE

$80 \%$

- Acute transmural myocardial infarction

- Chronic ischemic heart disease

$\triangle$ CARDIOMYOPATHIES

- Dilated cardiomyopathies

- Hypertrophic cardiomyopathies

$\triangleright$ VALVULAR / INFLAMMATION / INFILTRATION

$\triangle$ SUBTLE, POORLY-DEFINED LESIONS

$\triangleright$ LESIONS OF MOLECULAR STRUCTURE

$\triangle$ FUNCTIONAL ABNORMALITIES

$\triangleright$ "NORMAL" HEARTS - IDIOPATHIC VF

Figure 3. Etiologic basis of sudden cardiac death. Coronary heart disease and the cardiomyopathies collectively account for $>90 \%$ of all sudden cardiac deaths. (Modified from American Journal of Cardiology, Volume 80, Myerburg RJ, Interian A, Mitrani RM, Kessler KM, Castellanos A: Frequency of sudden cardiac death and profiles of risk, pages 10F-19F, Copyright 1997, with permission from Excerpta Medica, Inc.) coronary arteries, Brugada syndrome, and idiopathic ventricular fibrillation (VF) accounting for the majority of these deaths. Mortality risks for any one of these diagnoses is quite variable and may, in fact, have genetic predetermination of the magnitude of risk for sudden death as an expression of the specific mutation (see later).

The inverse relationship between the incidence of SCD and absolute numbers of events in the various epidemiologic or clinical categories is important to appreciate (Fig. 4), particularly in relationship to the impact of therapeutic interventions. ${ }^{15}$ Among the general population aged 35 years and older, the nominal incidence of $0.1 \%$ to $0.2 \%$ per year incorporates all of the estimated 300,000 sudden deaths that occur in the United States annually. With profiles of increasing risk from patients who fall into categories of high risk for development of coronary atherosclerosis, to those who have survived a coronary event, and beyond that to those with heart failure or ejection fractions $<35 \%$, cardiac arrest survivors and the specific high-risk postmyocardial infarction patients, the escalating risk accounts for a decreasing absolute number of events annually. The importance of recognizing this principle relates to the magnitude of population benefit for various preventative interventions. For example, the very high-risk patient categories studied in the clinical trials of implantable defibrillators (Fig. 4) represent only a very small part of the universe of SCD risk, and the reported benefits apply only to those small subgroups. This highlights the importance of finding specific risk markers for more general segments of the population from which the potential for greater public health impact can emerge.

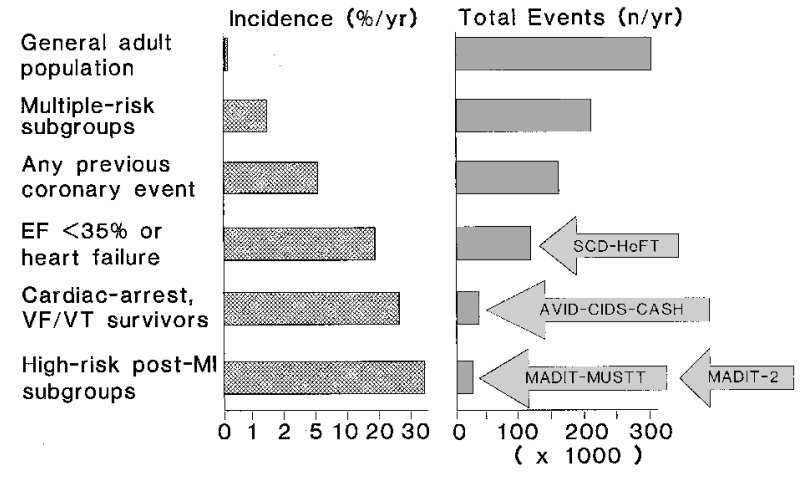

Figure 4. Relationship between population subsets, incidence of sudden cardiac death, and total population burden for each group. With increasing incidence, based on subgroup profiling, there is a decreasing proportion of the total sudden death burden. This relates to the population impact of the outcomes of ICD trials. (Modified from American Journal of Cardiology, Volume 80, Myerburg RJ, Interian A, Mitrani RM, Kessler KM, Castellanos A: Frequency of sudden cardiac death and profiles of risk, pages 10F-19F, Copyright 1997, with permission from Excerpta Medica, Inc.) 


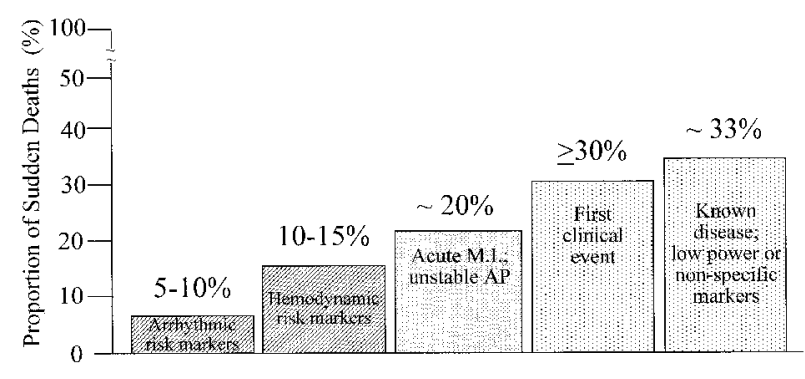

Figure 5. Subgroups at risk for sudden cardiac death within the category of ischemic heart disease. The population subset with highrisk arrhythmia markers constitute $<10 \%$ of the total sudden death burden attributable to coronary artery disease. A somewhat larger group is associated with hemodynamic risk markers and congestive heart failure. More than 50\% of the total sudden death burden is accounted for by those victims among whom sudden cardiac death is the first clinical event or those who have known coronary heart disease but low power of risk.

\section{Etiologic Basis of SCD and Profiling Individual Risk}

Coronary heart disease is the single most common cause of SCD in the United States and western Europe, accounting for approximately $80 \%$ of the deaths. ${ }^{16}$ However, coronary heart disease is expressed as a number of different clinical syndromes, and SCD in patients with coronary heart disease must be approached from the perspective of at least five different clinical settings and presentations. Figure 5 provides estimates of the proportion of each. Unfortunately, there is no single database that categorizes SCD expression in this way, and the estimates are approximations derived from a number of sources.

Much of the early attention to SCD risk focused on patients who had arrhythmic markers. This approach derived logically from the then-current theory of mechanisms of onset and maintenance of ventricular tachyarrhythmias. ${ }^{17}$ Study groups included postmyocardial infarction patients in whom risk was suggested on the basis of chronic ambient arrhythmias, ${ }^{18-20}$ presumed high-risk arrhythmic markers such as inducible ventricular tachyarrhythmias, ${ }^{21-23}$ or patients who survived manifest lifethreatening arrhythmias, including cardiac arrest $\mathrm{t}^{24,25}$ (Fig. 4). The role of the former category as a target for specific antiarrhythmic therapy fell to the adverse outcome observations from the Cardiac Arrhythmia Suppression Trial (CAST) ${ }^{26,27}$ and the Survival with Oral d-Sotalol (SWORD) Trial, ${ }^{28}$ but the other two categories continued in play in clinical trials of implantable cardioverter defibrillator (ICD) therapy. ${ }^{29-33}$ Unfortunately, risk profiling based on laboratory inducible arrhythmias and cardiac arrest survival constitute no more than $5 \%$ to $10 \%$ of the potential universe of SCD victims ${ }^{15,16}$ (Fig. 5). An additional category of interest, for which an important clinical trial is under way, are patients at potential risk for SCD based on the presence of left ventricular dysfunction and congestive heart failure (Fig. 4 ), in the absence of arrhythmia markers of risk. ${ }^{34}$ The population category in this trial-Sudden Cardiac Death in Heart Failure Trial (SCD-HeFT) - may account for an additional $10 \%$ to $15 \%$ of potential victims among the SCD universe (Fig. 5), an estimate based partly on projections derived from the growing prevalence of congestive heart failure. ${ }^{12,34}$

Another category of risk that has been long recognized is that of cardiac arrest occurring during the onset and early evolution of acute transmural myocardial infarction or unstable angina pectoris. These categories of acute coronary syndromes contribute another $20 \%$ to the SCD incidence..$^{35}$ Viewing the first three categories cumulatively and recognizing that they generate orders of magnitude of risk that are reasonable for effective intervention strategies ${ }^{15}$ (with SCD-HeFT results pending), more than $50 \%$ of cardiac arrests remain in the two clinical settings that are not included among patient groups addressed in the ICD trials or acute myocardial infarction. The residual groups include patients with defined coronary heart disease, who have a low total mortality risk because of the absence of high-risk markers for cardiac arrest or total mortality, and those victims among whom cardiac arrest is the first and only recognized clinical manifestation of coronary artery disease (Fig. 5). ${ }^{36}$

It is reasonable to accept the concept that specific arrhythmic markers, in conjunction with the extent of disease, provide a well-defined category of risk that can be benefitted by ICD therapy, ${ }^{29-33}$ and that SCDHeFT will either identify or put to rest the notion of preventable arrhythmic sudden death risk in a second sizeable category. There remains the need to identify risk markers for the rest of the SCD universe that will provide greater resolution of risk and, therefore, reasonable intervention applications. To achieve this goal, new approaches to risk identification will be required (Fig. 6).

In the early years of attention to risk factors for SCD,

Indicators of Risk of Sudden Arrhythmic Death

\begin{tabular}{|c|c|c|c|}
\hline RISK FACTORS & EXAMPLES & MEASURES & SENSITIVITY \\
\hline - Conventional & - Framingham risk & $\begin{array}{l}\text { - Predict evolution } \\
\text { of disease }\end{array}$ & - Very low \\
\hline - Anatomic & - Electron beam CT & - Abnormal arteries & - Very low \\
\hline \multirow[t]{2}{*}{ - Clinical } & - EF; angiography & - Extent of disease & $\begin{array}{l}\text { - Variable; } \\
\quad \text { low specificity }\end{array}$ \\
\hline & - AM; EPS & - Arrhythmic markers & $\begin{array}{l}\text { - Low-to-intermediate } \\
\text { for screening; high } \\
\text { in specific groups }\end{array}$ \\
\hline \multirow[t]{3}{*}{$\begin{array}{l}\text { - Transient risk } \\
\text { predictors }\end{array}$} & - EKG markers & $\begin{array}{c}\text { - T-wave alternans; } \\
\text { Q-T dispersion }\end{array}$ & $\begin{array}{l}\text { - Primary predictive } \\
\text { value unknown }\end{array}$ \\
\hline & $\begin{array}{l}\text { - Pathophysiological } \\
\text { controls (eg, HRV) }\end{array}$ & - Autonomic regulation & $\begin{array}{l}\text { - Uncertain; may be } \\
\text { useful }\end{array}$ \\
\hline & - Inflammation & - Predict unstable plaques & $\begin{array}{l}\text { - Unknown; potentially } \\
\text { high }\end{array}$ \\
\hline $\begin{array}{l}\text { - Individual risk } \\
\text { predictors }\end{array}$ & $\begin{array}{l}\text { - Familial/genetic } \\
\text { profile }\end{array}$ & - Specific SCD risk & $\begin{array}{l}\text { - Unknown; potentially } \\
\text { high }\end{array}$ \\
\hline
\end{tabular}

Figure 6. Indicators of risk of sudden arrhythmic death. The conventional risk factors and anatomic disease screening have some general use for predicting risk, but sensitivity is very low and nonspecific for arrhythmic deaths. Transient risk predictors and individual risk predictors offer the hope for more powerful individual prediction of sudden cardiac death.) 
Plaque Anatomy in Sudden Cardiac Death $(\mathrm{n}=79)$

$\begin{array}{lcc} & \underline{\mathrm{n}} & \% \\ \text { STABLE PLAQUE } & 27 & 34 \% \\ \text { PLAQUE EROSION } & 22 & 28 \% \\ \text { PLAQUE RUPTURE } & 30 & 38 \%\end{array}$

Figure 7. Pathologic anatomy of coronary arteries in sudden cardiac death victims. Plaque rupture or erosion was observed in approximately 2 of 3 of victims studied. (Data derived from reference 59.)

the recognition of the major role played by coronary artery disease led to the use of conventional risk factors for coronary artery disease as a predictor of risk of SCD. ${ }^{37}$ From a statistical viewpoint, this was reasonable because of the large proportion and numbers of SCDs that were attributable to coronary artery disease. This concept is limited, however, by the fact that these risk factors largely predict the evolution of the disease and identify orders of magnitude of risk that are too low for specific antiarrhythmic interventions. They do not provide a specific marker of risk for arrhythmic deaths. Other methods for identifying the presence of structural abnormalities in coronary arteries have been suggested as potential strategies to provide greater sensitivity and specificity. For example, anatomic disease screening, with the use of electron beam computerized tomography, has been suggested as a method for large-scale screening to identify abnormal coronary arteries. ${ }^{38}$ It is limited by the fact that identification of the structural abnormality does not identify specific markers of arrhythmic risk. It also is limited by its inability to estimate the extent and activity of specific lesions. Much of the progress that has been made to date in profiling risk of SCD has been based on clinical markers that primarily identify the extent of disease, either at the myocardial or vascular level. Although resolution of overall risk is more powerful, it is still nonspecific because of its general inability to discriminate arrhythmic death from other forms of death.

To achieve better profiling of arrhythmic risk, two approaches appear promising for the future. One is predictors of transient risk, which are intended to identify those individuals who are at risk for the transient events that trigger fatal arrhythmias ${ }^{9,15,39-41}$ (Fig. 6). These include pathophysiologic control mechanisms, mediated through autonomic nervous system functions such as heart rate variability ${ }^{42-44}$ or baroreceptor sensitivity, ${ }^{45}$ measures of repolarization alterations such as $\mathrm{T}$ wave alternans ${ }^{46,47}$ or QT dispersion, ${ }^{48}$ and inflammatory markers, ${ }^{49-52}$ which are being evaluated as a predictor of risk for plaque destabilization, the latter being a clear marker for acute coronary syndromes. Although the inflammatory markers for plaque disruption may provide higher resolution of risk for acute coronary syndromes generally, ${ }^{53,54}$ indi- vidual risk predictors, such as familial or genetic profiling, might provide even greater resolution for SCD risk in specific individuals. With regard to the latter, recent studies suggested familial clustering of cardiac arrests as a specific clinical expression of acute coronary events ${ }^{55,56}$ that might derive from a genetic predisposition.

Among the multiple pathologic and pathophysiologic studies demonstrating that coronary atherosclerotic plaque erosion or rupture correlates with acute coronary syndromes are those that demonstrate its significance in $\operatorname{SCD}^{57-59}$ (Fig. 7). The ability to identify the individual at risk for plaque disruption, in advance of an acute coronary syndrome, might provide a powerful method for identifying individuals at potential risk of SCD. Among the factors being evaluated for this role are indices of chronic plaque inflammation. In recent retrospective studies of men ${ }^{50}$ and women, ${ }^{52}$ in whom both cholesterol levels and indices of inflammation could be correlated with risk of coronary events, it was observed that each appeared to provide an independent predictive value and that the combination had the strongest power of prediction of relative risk increase. High-sensitivity C-reactive protein used in the study among women ${ }^{52}$ discriminated inflammatory markers of risk from cholesterol-related risk particularly well. However, because the outcomes were expressed as relative increases of a baseline risk among the subjects in the lowest terciles of cholesterol and inflammatory marker concentration, the absolute contribution of inflammatory markers (compared with cholesterol markers) remains to be determined. If the order of magnitude of absolute risk predicted by inflammatory markers is considerably higher than that of cholesterol markers, a new marker of risk with greater potential power of resolution of risk may become available. A recent observation suggesting that complex plaques may be multiple, suggesting a generalized susceptibility to plaque disruption (rather than plaque-specific risk) and a higher recurrent event rate after myocardial infarction, ${ }^{60}$ supports the notion of inflammation-based susceptibility. Other direct and indirect markers of risk of

\begin{tabular}{|c|c|c|c|c|}
\hline $\begin{array}{l}\text { Hx of Parental } \\
\text { Sudden Death }\end{array}$ & $\begin{array}{c}\operatorname{SCD} \\
|n=118|\end{array}$ & $\begin{array}{l}\text { FATAL M.I. } \\
{[\mathbf{n}=192]}\end{array}$ & $\begin{array}{c}\text { CONTROLS } \\
|n=6,762|\end{array}$ & $\mathbf{p}$ \\
\hline Events & $\begin{array}{c}22 \\
{[18.6 \%]}\end{array}$ & $\begin{array}{c}19 \\
{[9.9 \%]}\end{array}$ & $\begin{array}{c}--- \\
{[718,10.6 \%]}\end{array}$ & 0.02 \\
\hline $\begin{array}{l}\text { Relative } \\
\text { Risk }\end{array}$ & $\begin{array}{c}1.95 \\
{[p=.005]}\end{array}$ & $\begin{array}{l}0.97 \\
{[p=N S]}\end{array}$ & & \\
\hline $\begin{array}{l}\text { Absolute } \\
\text { Risk w/ (+) Hx }\end{array}$ & $\begin{array}{c}2.90 \% \\
{[22 / 759]}\end{array}$ & $\begin{array}{c}2.50 \% \\
{[19 / 759]}\end{array}$ & $\begin{array}{l}--- \\
{[718 / 759]}\end{array}$ & \\
\hline
\end{tabular}

Figure 8. Familial clustering of sudden cardiac death. These data from the Paris Prospective Study suggest that a parental history of sudden arrhythmic death is a strong predictor of sudden death in a long-term observational study. (Modified with permission from Jouven X, Desnos $M$, Guerot C, Ducimetiere P: Predicting sudden death in the population: The Paris Prospective Study I. Circulation 1999;99:1978-1983.) 


Chromosome
\begin{tabular}{|c|c|c|c|c|c|c|}
\hline 1 & LQT (R-W) & LQT (J, L-N) & HCM & RVD & Brugada \\
2 & & & cTnT & RYR2 & \\
3 & & & & $?$ & \\
4 & SCN5A & & MELC & $?$ & SCN5A \\
7 & $?$ & & & & \\
10 & HERG & & $?$ & & \\
11 & KvLQT1 & KvLQT1 & MyPBC & & \\
12 & & & MRLC & & \\
14 & & & $\beta-M H C$ & $?$ & \\
15 & & & $\alpha$-TM & & \\
17 & & & & plakoglobin & \\
19 & & & CTnI & [Reessive] & \\
21 & minK, MiRP1 & minK, MiRP1 & & & \\
\hline
\end{tabular}

Figure 9. Chromosome loci and specific genes, mutations of which are associated with sudden cardiac death syndromes. These are appropriate candidate genes for initial search for a genetic basis for familial clustering of sudden cardiac death risk. See text for details.

plaque destabilization from inflammatory processes also might contribute to this theory of risk prediction. ${ }^{52,61}$

Familial clustering of SCD suggests a different and potentially additive benefit to risk resolution. Figure 8 summarizes data from the Paris Prospective Study on risk factors for SCD. ${ }^{56}$ These data identified the fact that a history of parental sudden death predicted sudden death as the expression of an acute coronary event, with a nearly twofold increase in relative risk. Family history of SCD had no impact on risk of nonsudden fatal myocardial infarction. A similar observation was reported from a retrospective analysis of cardiac arrest survivors in King County, Washington. ${ }^{55}$ Family clustering may result from either cultural/environmental influences or genetic factors. Although the King County study was inconclusive in regard to this distinction, the prospective study from Paris suggested a genetic basis, because the gradient of risk increased when both parents had a family history of SCD. Recent progress in the study of the genetic syndromes that associate with sudden death risk provides a series of candidate genes (Fig. 9), mutations, or polymorphisms that set the stage for abnormal function in the setting of acute ischemia, even if phenotypically normal at baseline. Support for the general concept of genetic variations that do not affect baseline phenotype, but do express effects during a transient event, has been emerging. ${ }^{62}$ Most of the candidate genes cited control ion channel structure and function or contractile protein abnormalities, and provide initial targets for testing this general hypothesis. Other candidates may be identified in the future.

A hypothetical risk cascade for predicting SCD in individuals is shown in Figure 10. It is based on the identification of conventional coronary heart disease risk factors, refined by subsequent identification of plaque characteristics that would predispose to acute coronary syndromes and further refined by identifying specific individuals at risk based on arrhythmia markers, familial clustering, or genetic determinants. This risk model, subject to modification with emerging data, hopefully will lead to much more powerful risk resolution. The goal is
Cascade for Modeling Specific Risk of Sudden Cardiac Death

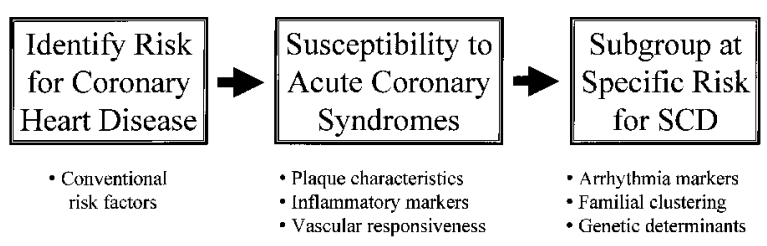

Figure 10. Hypothetical cascade for modeling individual-specific risk for sudden cardiac death. See text for details.

to identify subgroups of patients within general populations with very high specific risk for SCD who will be candidates for selective clinical prevention strategies.

\section{Clinical Strategies for Preventing SCD}

Early strategies for preventing SCD centered around the use of antiarrhythmic drugs, guided by either suppression of ambient ventricular arrhythmias or by the results of serial electrophysiologic studies. ${ }^{63}$ These approaches were used in several categories of patients for primary or secondary prevention of SCD. It is important to recognize that the terms "primary" and "secondary," as used in SCD trials, differ from the conventional definitions of primary and secondary prevention. The former properly refers to prevention of underlying disease rather than a manifestation of the disease; any other preventative strategy in the presence of disease is considered secondary.

Before the initial clinical introduction of the ICD in 1980, antiarrhythmic drugs and surgery were the only options available. With the emergence of ICDs, their use initially was prescribed on the basis of clinical judgment, without clinical trial data available to identify benefit, and their use compared with drugs and surgery moved forward slowly. Finally, in 1996, the first clinical trial comparing ICDs and antiarrhythmic drugs was published, ${ }^{29}$ and several additional trials were published subsequently..$^{30-33}$ The results have moved the ICD into the position of preferred therapy for specifically defined high-risk patients. The clinical trials of implantable defibrillators have included both primary and secondary prevention strategies. Although the usage of the term "primary prevention" for ICD trials is technically incorrect, it does serve the purpose of subgrouping patients into two general categories, the study design and outcomes of which might be interpreted and applied differently.

Any study of outcomes of therapy for complex pathophysiologic disorders must take four factors into consideration (Fig. 11): (1) relative risk reduction, (2) absolute risk reduction, (3) residual risk, and (4) cumulative benefit with other interventions. The primary endpoint reports for all clinical trials of ICD therapy, and most other large clinical trials as well, focus primarily on reduction in relative risk. ${ }^{64,65}$ This is the natural consequence of the mind set of clinical trial goals, which is to identify the 


\section{VARIABLE}

- Relative Risk Reduction

- Absolute Risk Reduction

- Residual Risk

- Cumulative Benefit

\section{PARAMETER}

Proportional difference; group effect

Numeric difference; individual impact

Absolute outcome among treated (comparison) group

Incremental benefits from multiple interventions

Figure 11. Outcomes measures for clinical trials.

effect of the intervention. However, it does not quantify the effect for the individual patient. To do so requires some measure of absolute risk reduction, either the absolute numerical difference in risk observed in the test and control groups, or calculations of the number of patients needed to be treated (NNT) in order to save a life. 66

Other measures of impact that do not commonly receive attention include residual risk and cumulative benefit. The former refers to the absolute outcome among the treated group or test group in a clinical trial population, which identifies the component of total mortality risk that does not respond to the tested therapy. If residual risk is very high, the absolute and relative risk reduction benefits are correspondingly limited. Cumulative benefit refers to the increment in benefit from integration of multiple interventions. This is rarely stratified in clinical trial designs because it requires larger study populations and has never been used prospectively in any of the defibrillator or antiarrhythmic trials. Post hoc subgroup analysis can be used to suggest added benefit of a secondary strategy, but this does not replace stratifying according to multiple interventions.

Comparison of the various measures of outcomes from an ICD trial, contrasted with another cardiovascular intervention, is shown in Figure 12. The relative and absolute outcomes observed in the Antiarrhythmics Versus Implantable Device study (AVID) ${ }^{30}$ at 2-year follow-up are compared with the West of Scotland Coronary Prevention Study (WOSCOPS), ${ }^{67}$ a study of the impact of pravastatin (Pravachol) versus placebo in a population of men without known preexisting coronary artery disease. Although the relative risk reduction for total mortality (at 2-year follow-up in AVID and 5-year follow-up in WOSCOPS) was reasonably close (27\% vs $22 \%$ ), the absolute risk reduction and residual risks were very different. The absolute benefit in AVID was $7 \%$ over 2 years, whereas in the WOSCOPS, the absolute total mortality benefit was $0.9 \%$ over a study period of 5 years. In addition, the residual risk in AVID was considerably higher than in the WOSCOPS population, as might be expected for the populations in the two studies. The high residual risk in AVID dwarfs, to some extent, the absolute risk reduction.
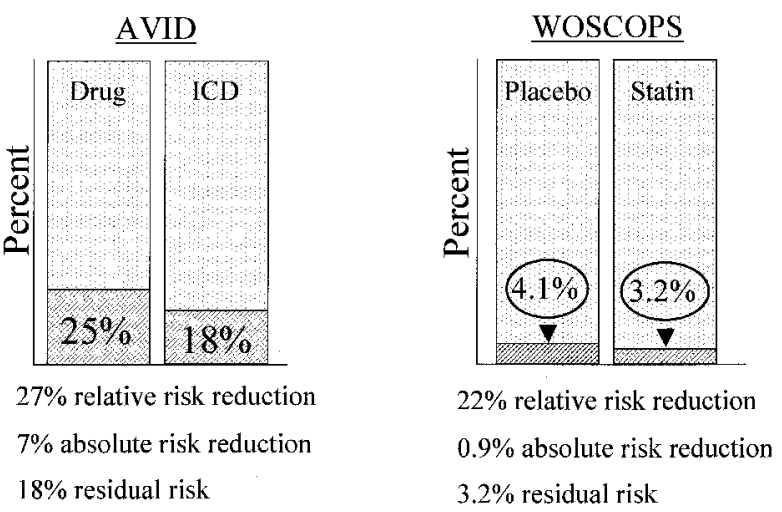

Figure 12. Total mortality benefit for an ICD trial (AVID) and a trial of a statin for reducing cardiovascular events (WOSCOPS). Relative and absolute risk reductions are indicated along with residual risks. See text for details. (Modified with permission from Myerburg RJ, Mitrani R, Interian A Jr, Castellanos A: Interpretation of outcomes of antiarrhythmic clinical trials. Design features and population impact. Circulation 1998;97:1514-1521; and Shepherd J, Cobbe SM, Ford I, Isles CG, Lorimer AR, MacFarlane PW, McKillop JH, Packard CJ: Prevention of coronary heart disease with pravastatin in men with hypercholesterolemia. West of Scotland Coronary Prevention Study Group. N Engl J Med 1995;333:1301-1307. Copyright (C) 1995 Massachusetts Medical Society. All rights reserved.)

In another comparison, ICD use versus amiodarone (AVID) and cessation of cigarette smoking among survivors of out-of-hospital cardiac arrest ${ }^{68}$ both identify absolute and relative risk benefits of the same general order of magnitude. However, these two separate observations beg the question of whether there is a positive interaction between cigarette smoking cessation and the ICD. Does the cessation of cigarette smoking identify a patient population among whom ICD benefit is even greater and residual risk lower, or does cessation of cigarette smoking account for, and neutralize, some of the apparent ICD benefit? Subgroup analyses are not sufficient to answer these questions. Cessation of cigarette smoking is but one of a number of interventions that could be tested in parallel with ICD therapy, seeking

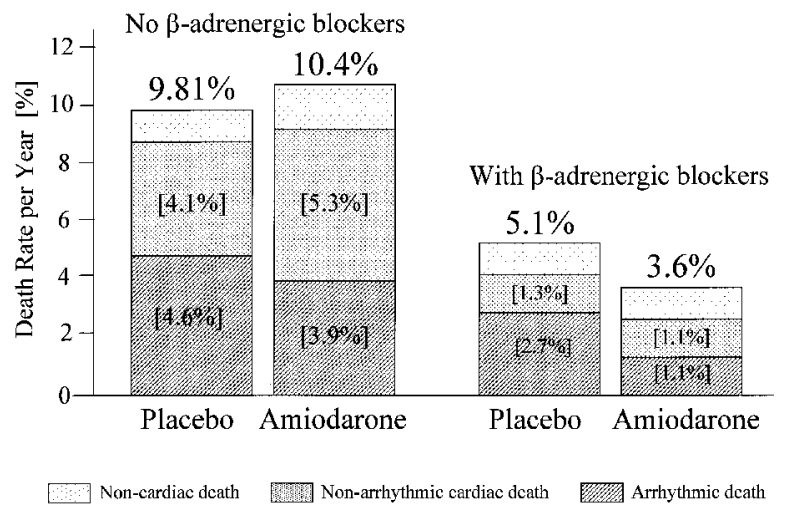

Figure 13. Positive interaction between amiodarone and beta blockers in EMIAT and CAMIAT. See text for details. 


\begin{tabular}{|c|c|c|c|c|}
\hline Deployment & Examples & $\underline{\text { Rescuers }}$ & Advantages & Limitations \\
\hline $\begin{array}{l}\text { Emergency } \\
\text { Vehicles }\end{array}$ & $\begin{array}{l}\text { - Police patrol cars } \\
\text { - Fire engines } \\
\text { - Ambulances }\end{array}$ & $\begin{array}{l}\text { - Trained emergency } \\
\text { personnel }\end{array}$ & $\begin{array}{l}\text { - Experienced users } \\
\text { - Broad deployment } \\
\text { - Objectivity }\end{array}$ & $\begin{array}{l}\text { - Deployment time } \\
\text { - Arrival delays } \\
\text { - Community variations }\end{array}$ \\
\hline $\begin{array}{l}\text { Public } \\
\text { Access }\end{array}$ & $\begin{array}{l}\text { - Public buildings } \\
\text { - Stadiums and malls } \\
\text { - Airports; airliners }\end{array}$ & $\begin{array}{l}\text { - Security personnel } \\
\text { - Designated rescuers } \\
\text { - Random lay persons }\end{array}$ & $\begin{array}{l}\text { - Population density } \\
\text { - Shorter delays } \\
\text { - Lay and emergency } \\
\text { personnel access }\end{array}$ & $\begin{array}{l}\text { - Low event rates } \\
\text { - Inexperienced users } \\
\text { - Panic and confusion }\end{array}$ \\
\hline $\begin{array}{l}\text { Multi-family } \\
\text { Dwellings }\end{array}$ & $\begin{array}{l}\text { - Apartment building } \\
\text { - Condominium } \\
\text { - Hotels }\end{array}$ & $\begin{array}{l}\text { - Security personnel } \\
\text { - Designated rescuers } \\
\text { - Family members } \\
\text { - Random lay persons }\end{array}$ & $\begin{array}{l}\text { - Familiar locations } \\
\text { - Defined personnel } \\
\text { - Shorter delays }\end{array}$ & $\begin{array}{l}\text { - Infrequent use } \\
\text { - Low event rates } \\
\text { - Geographic factors }\end{array}$ \\
\hline $\begin{array}{l}\text { Single-family } \\
\text { Dwellings }\end{array}$ & $\begin{array}{l}\text { - Private homes } \\
\text { - Apartments }\end{array}$ & $\begin{array}{l}\text { - Family members } \\
\text { - Bystanders }\end{array}$ & $\begin{array}{l}\text { - Rapid access } \\
\text { - Familiar setting }\end{array}$ & $\begin{array}{l}\text { - Acceptance } \\
\text { - One-time user; recall } \\
\text { - Victim alone } \\
\text { - Panic }\end{array}$ \\
\hline
\end{tabular}

Figure 14. Strategies for automatic external defibrillator deployment, comparing deployment approaches, rescuers, and limitations.

positive interactions. The general principle has been suggested for amiodarone and beta blockers in postmyocardial infarction patients. ${ }^{69}$ Combined retrospective analysis of data from CAMIAT and EMIAT suggest that such a principle operates in these trials (Fig. 13)..$^{70,71}$ Finally, for two major ICD trials (MADIT ${ }^{29}$ and AVID $^{30}$ ), concern about beta-blocker imbalances in the ICD test groups has not focused on the possibility that beta blockers and ICDs provide cumulative benefit, as in EMIAT and CAMIAT. The notion of cumulative benefit is worthy of further study.

\section{Community Programs for Cardiac Arrest Survival}

Community-based approaches, targeted at reducing the incidence of SCD by improving outcomes from outof-hospital cardiac arrests, can take multiple forms. These include mass screening programs for identifying individuals at risk, public information and education programs for enhancing intervention strategies, and implementation of community-based response systems. The latter include extensions of emergency medical services and strategies using automatic external defibrillators (AEDs), either through organized response systems, general public access programs, or deployment in private facilities (Fig. 14).

The initial strategy for responding to cardiac arrest in communities engaged interested physicians with fire department and paramedical personnel. The first systems were developed simultaneously in the cities of Seattle, Washington, and Miami, Florida. The initial outcomes, measured as survival to hospital discharge, were $14 \%$ in Miami $^{72}$ and $11 \%$ in Seattle. ${ }^{73}$ From the publication of these data in 1974 to the present, a series of changes have occurred, generating both optimistic and pessimistic data (Fig. 15). After the initial Miami and Seattle publications, a series of advances in systems and personnel deployment $t^{7,75}$ and encouragement of bystander cardiopulmonary resuscitation ${ }^{76}$ resulted in a sharp increase in survival rates in communities with highly organized systems and committed investigators. These advances were led largely by the Seattle experience, which led to a peak survival rate in the range from $30 \%$ to $35 \%$ between the late 1970s and mid-1980s. ${ }^{77}$ At the same time, it was

History of Out-of-Hospital Cardiac Arrest Surviva

\begin{tabular}{rlr}
\hline \hline 1971-1974 & Initial Miami/Seattle Outcomes & $14 \%, 11 \%$ \\
$1978-1985$ & Peak Miami/Seattle Outcomes & $25-35 \%$ \\
1984 & Rural Outcomes: & \\
& $\quad$ - Standard Basic life Support & $3 \%$ \\
1991 & - Ambulance-based Expanded Access & $19 \%$ \\
$1992-1994$ & Major Metropolitan Population Centers & $1-3 \%$ \\
1996 & Dade County, Florida, Current Outcomes & $\leq 2 \%$ \\
$1996-1998$ & Current U.S. EMS Outcomes, Cumulative & $\sim 5 \%$ \\
1999 & "Optimizcd" Systcms \{OPALS & $5 \%$
\end{tabular}

Figure 15. History of out-of-hospital cardiac arrest survival experiences under different circumstances between 1970 and 1999. Based on considerations outlined in the text, standard emergency rescue systems are not sufficient to have a major impact on sudden cardiac death in the current era. New strategies allowing faster response times are required. 
A

Swedish Cardiac Arrest Registry

Delay / Survival for VT/NF in Initial ECG

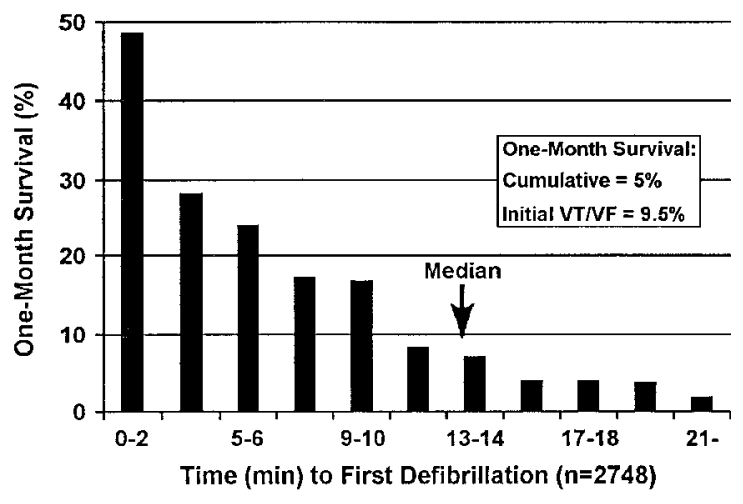

[FROM: Holmberg M, et al; Am J Cardiol 1999]

\section{B Amsterdam Resuscitation Study}

Response Times of Police and EMS

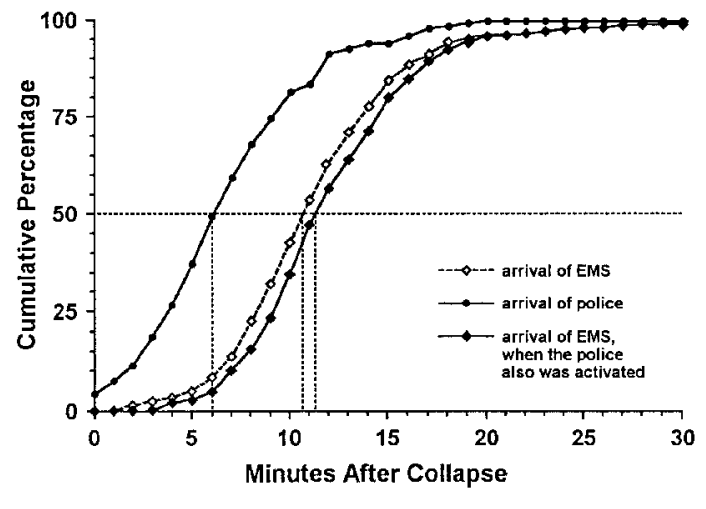

[FROM: Waalewijn RA, et al; Resuscitation 1998]

Figure 16. Response times in cardiac arrest. (A) Response time versus survival in ventricular tachycardia and ventricular fibrillation from the Swedish Cardiac Arrest Registry. (Modified from American Journal of Cardiology, Volume 83, Holmberg M, Holmberg S, Herlitz J: The problem of out-of-hospital cardiac-arrest: Prevalence of sudden death in Europe today, pages 88D-90D, Copyright 1999, with permission from Excerpta Medica, Inc.) (B) Potential impact of police deployment observed in the Amsterdam Resuscitation Study (ARREST). (Modified from Resuscitation, Volume 38, Waalewijn RA, de Vos R, Koster RW: Out-of-hospital cardiac arrests in Amsterdam and its surrounding areas: Results from the Amsterdam resuscitation study [ARREST] in “Utstein" style, pages 157-167, Copyright 1998, with permission from Elsevier Science.)

becoming apparent that systems had to be tailored to specific community circumstances in order to be effective. For example, early outcomes in rural communities were disappointing, compared to the Seattle and Miami data. In a study from Iowa, standard basic life support in rural areas (communities of 10,000 population or less) yielded a survival rate of only $3 \%$. However, when those communities expanded access through ambulance-based defibrillator response systems, the outcomes improved to $19 \% .^{78}$ This was among the first of the meaningful examples of expanded access as a method for improving survival.

Despite the encouraging data forthcoming from a number of communities, the cumulative U.S. survival rate from cardiac arrest was estimated to be in the range from $1 \%$ to $3 \%$ as recently as $1991 .^{79}$ This apparently resulted in part from limited rapid access to rescue systems, and in part from the fact that not all cardiac arrest victims had response systems available to them. Shortly thereafter, a major disappointment evolved from large metropolitan population centers such as New York and Chicago, in which emergency rescue systems yielded cardiac arrest survival rates of $1.4 \%{ }^{80}$ and $2 \%,{ }^{81}$ respectively. The reasons for these outcomes were likely multifactorial, including population characteristics, traffic congestion, and vertical development of communities, and resulting adverse effects on response times. More recently, overall estimates of survival outcomes from cardiac arrest are in the range of approximately $5 \%$ using conventional or enhanced response systems, ${ }^{82,83}$ although there is reason for optimism based on preliminary data from police car-based and other AED programs.

There is increasing appreciation of a potential role for AEDs deployed in police vehicles, ${ }^{84}$ even though com- prehensive data demonstrating an incremental benefit in communities with disappointing outcomes are still lacking. ${ }^{85}$ The rationale for the approach derives from the clear relationship between time to defibrillation and survival. Figure 16A shows the data from the Swedish Cardiac Arrest Registry (SCAR), in which cardiac arrest due to VF among more than 2,700 victims showed a clear time relationship between time to defibrillation and survival. ${ }^{86}$ Even within the first 2 minutes of cardiac arrest, survival rates were $<50 \%$, but the major point of these data is that the survival attrition is very steep between 2 and 10 minutes, reaching approximately $10 \%$ survival at 10 minutes and continuing to decay after that.

The rationale for AED deployment is to shorten the response time and the question of whether police can effectively do this in a major city has been clarified in part by data from Amsterdam, The Netherlands, and Miami, Florida. The Amsterdam data (ARREST) (Fig. 16B) demonstrated a mean time benefit of approximately 5 minutes by dual response of fire rescue and police in a single segment of the city of Amsterdam. ${ }^{87}$ Preliminary data based on deployment of AEDs in all of the MiamiDade County, Florida, police cars has suggested a shift in the response time curve, yielding a mean police response time of 4.9 minutes from 911 call, compared with 8.1 minutes for fire rescue response. ${ }^{88}$

Recent data from Rochester, Minnesota, do not show a clear added benefit for overall survival by police responders compared to paramedic responders. ${ }^{84}$ In that particular community, however, the differential response time between police and paramedics was $<1$ minute, which would lead one to expect little difference in benefit. Viewed another way, the similar times reflecting similar outcomes support the notion that police respond- 


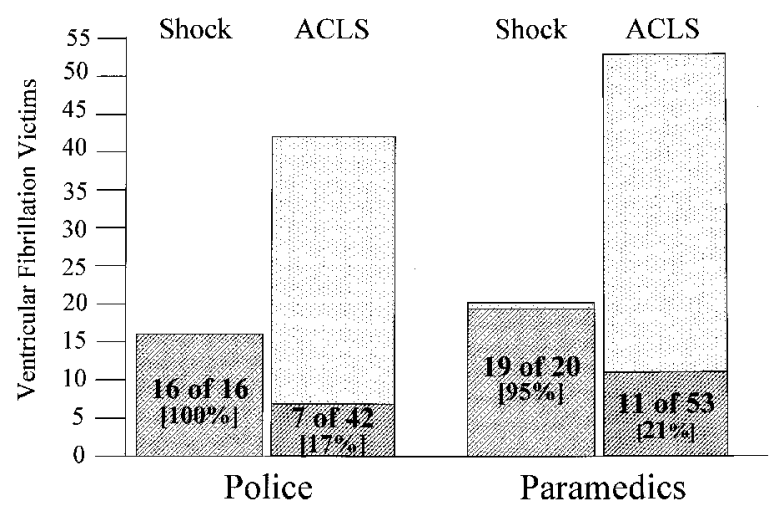

Figure 17. Comparison of outcomes for police responders and paramedic responders from the Rochester, Minnesota experience. Outcomes among those victims who have returned to spontaneous circulation with shock alone versus those who required advanced cardiac life support (ACLS) are shown. In this community, the response time differences between police and paramedics were $<1$ minute, and the data support the notion that both police and paramedics are effective responders. (Modified from Resuscitation, Volume 39, White RD, Hankins DG, Bugliosi TF: Seven years' experience with early defibrillation by police and paramedics in an emergency medical services system, pages 145-151, Copyright 1998, with permission from Elsevier Science.)

ers are effective (Fig. 17). Accordingly, in larger communities in which traffic congestion and driving time are important variables, a potential benefit of police deployment is related to the fact that they are already on the road when a 911 call comes in. The extent to which police-based AEDs will improve survival is still unknown. In some communities, there has been concern about failure of police to respond to cardiac arrests, but the design system used in Miami-Dade County largely supersedes this problem by a tiered system for responses to conventional police calls when a medical response is in progress.

Another area in which there has been increasing attention to the potential role of AEDs is in airports and in-flight airliners. The initial published data from the Qantas Airline experience, in which airports and transPacific airliners were equipped with AEDs in the early 1990s, suggested effectiveness in airports, but limited benefit in flight ${ }^{89}$ (Fig. 18). The ground-based responses in major airports in Australia demonstrated that $79 \%$ of the cardiac arrests were identified to be shockable rhythms (ventricular tachycardia [VT]/VF), and the cumulative survival rate among those victims was $21 \%$ (24\% among the VT/VF subgroup). In contrast, the initial in-flight data from the Qantas program demonstrated that only 6 of 27 events were due to recognized shockable rhythms (22\%), although 2 of those 6 did survive. ${ }^{89}$ More disappointing was the observation that 21 (78\%) of the victims had bradyarrhythmias or asystole. Among these, about half were thought to have been asleep when they were actually in cardiac arrest and were found to be asystolic when finally responded to. The other half appeared to have had primary bradyarrhythmic events, still

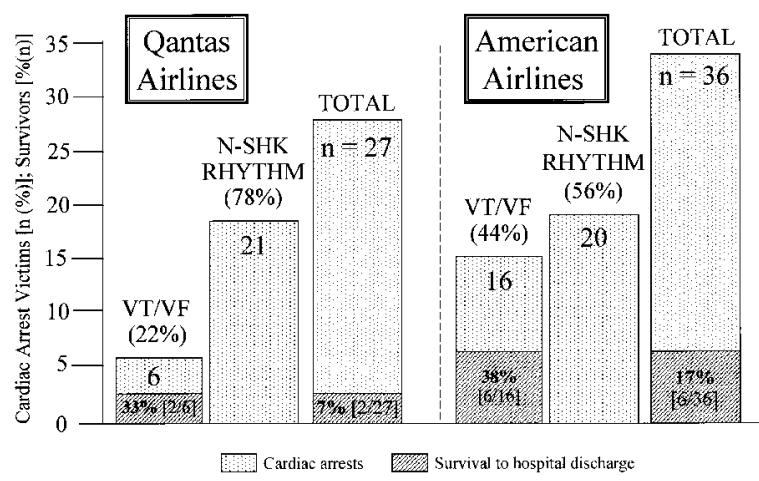

Figure 18. Impact of automatic external defibrillators (AEDs) on cardiac arrest survival in airlines. The Qantas Airline data was dominated by nonshockable rhythms (N-SHK), but 2 of 6 victims who had ventricular fibrillation (VF) in-flight survived. The American Airlines data have a lesser excess of N-SHK, although they were still the majority of events. Among victims with ventricular tachycardia (VT)/ $V F$, there was a $38 \%$ survival rate (intention-to-treat). Total outcome, including $N$-SHK events, was a $17 \%$ cumulative survival. (Data derived from references 89 and 90.)

in excess compared with ground-based experience. Subsequent data from American Airlines also demonstrated that the majority of cardiac arrests in the air were due to nonshockable rhythms, although the proportion of nonshockable rhythms was lower..$^{90}$ Among the victims who had shockable rhythms, there was a $38 \%$ survival rate, based on intention-to-treat analysis, yielding an overall survival rate among all mechanisms of cardiac arrest of approximately $17 \%$. This is comparable to the better of ground-based experiences today.

The reason for the excess of bradyarrhythmic events during flight is only partially clarified by the fact that some of the victims were thought to be sleeping. ${ }^{89}$ One issue that may be operative is the relationship between arterial oxygen saturation at cruise altitudes in airliners and the propensity to, or maintenance of, VF in that environment. It is well established from aerospace data that, at a pressurized altitude of 7,000 to 9,000 feet, the partial pressure of oxygen $\left(\mathrm{pO}_{2}\right)$ is reduced by about $50 \%$ compared with sea level and the oxygen saturation in arterial blood is reduced as well, even among normal individuals. ${ }^{91}$ Figure 19 demonstrates data from a single experience with monitoring of arterial $\mathrm{O}_{2}$ saturation during a commercial airline flight from Miami to Chicago. During cruise, at an altitude of 37,000 feet with a cabin altitude pressure of 7,700 feet, the resting arterial oxygen saturation hovered around $90 \%$, and with light exercise fell to approximately $85 \%$. This is an expected response of little apparent clinical significance during normal cardiovascular physiology. However, it may become relevant during the onset and maintenance of cardiac arrest, because hypoxemic states tend to associate with a higher probability of bradyarrhythmic arrests or pulseless electrical activity compared to tachyarrhythmic arrests. There are some experimental data suggesting that the maintenance of $\mathrm{VF}$ before progressing to asystole is 
related to $\mathrm{O}_{2}$ availability.92 This is an area of investigation which requires further development, since it may impact on outcome expectations.

AED deployment strategies are being considered in settings beyond those described. Deployment strategies can be categorized into four categories, as demonstrated in Figure 14. The advantages and limitations of each of the approaches are listed. The most rational approach to the determination of the validity of AED deployment strategies is based on development of scientific support for their efficacy and incremental benefit over conventional systems. This is best done by observations of well-controlled emergency systems initially, such as police and ambulance-based deployments, and simultaneously by extension into other public access sites in which a broader array of personnel are trained to use the devices. ${ }^{93}$ These might include security personnel in public buildings, stadiums, airports, and shopping malls. Studies are under way to determine the impact of such deployments. Beyond that, AED deployment in multifamily dwellings, best controlled by defined users such as security personnel, is used sporadically and should be scrutinized with a carefully designed registry study. There was optimism about AED use in single-family dwellings at the time of the initial development of AEDs in the early 1980s, but this has ameliorated in part because of the growth of implantable defibrillator use in higher risk patients and some of the limitations that were experienced in single-family dwelling deployments.

\section{Expanding the Limits of Our Knowledge and Opportunities}

Major expansions of our knowledge base and practical capabilities for preventing SCD will depend on a partnership among medical and nonmedical components of society. Clinical and basic science investigators and clinicians can only carry the message a limited distance and cannot themselves provide the support, tools, and research funding for making major advances. It is incumbent upon physicians interested in the problem of SCD to link closely with the media and the public to encourage awareness and action. Major steps forward will require

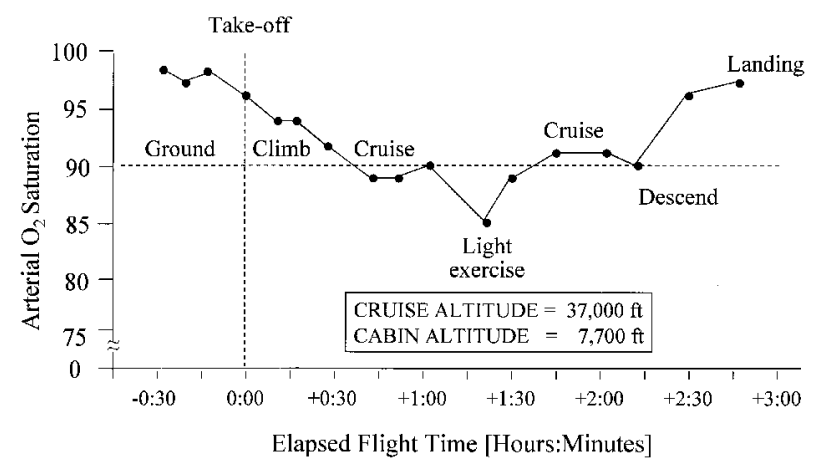

Figure 19. Effect of cabin altitude during airline flight on arterial $\mathrm{O}_{2}$ saturation. public and political support, not just new scientific data and opinions of the medical profession. To the extent that interested physicians are willing to extend their conventional roles into community linkages, public action, and political involvement, we will continue to observe incremental impact on the problem of SCD.

\section{References}

1. Weiss S: Instantaneous "physiologic" death. N Engl J Med 1940; 223:793-797.

2. Spain DM, Bradess VA, Mohr C: Coronary atherosclerosis as a cause of unexpected and unexplained death: An autopsy study from 1949-1959. JAMA 1960;174:384-388.

3. Kuller L, Lilienfield A, Fisher R: An epidemiological study of sudden and unexpected deaths in adults. Medicine 1967;46:341361.

4. Epstein FH, Pisa Z: International comparisons in ischemic heart disease mortality. In: Proceedings of the Conference on Decline in Coronary Heart Disease Mortality. DHEW, NIH Publication No. 79-1610, U.S. Government Printing Office, Washington, DC, 1979, pp. 58-88.

5. Report of the Working Group on Arteriosclerosis of the National Heart, Lung, and Blood Institute (Volume 2): Patient Oriented Research-Fundamental and Applied, Sudden Cardiac Death. DHEW, NIH Publication No. 82-2035. U.S. Government Printing Office, Washington, DC, 1981, pp. 114-122.

6. Escobedo LG, Zack MM: Comparison of sudden and nonsudden coronary deaths in the United States. Circulation 1996;93:2033 2036.

7. Manolio TA, Furberg CD: Epidemiology of sudden cardiac death. In Akhtar M, Myerburg RJ, Ruskin JN, eds: Sudden Cardiac Death: Prevalence, Mechanisms, and Approaches to Diagnosis and Management. Williams \& Wilkins, Malvern, PA, 1994, pp. 3-20.

8. Myerburg RJ, Castellanos A: Cardiac arrest and sudden cardiac death. In Braunwald E, ed: Heart Disease: A Textbook of Cardiovascular Medicine. Sixth Edition. WB Saunders, Philadelphia, 2001, pp. 890-931.

9. Myerburg RJ, Kessler KM, Castellanos A: Sudden cardiac death. Structure, function, and time-dependence of risk. Circulation 1992; 85(Suppl I):I-2-I-10.

10. Lewis RP: The ACC at 50: A giant grew in Bethesda. J Am Coll Cardiol 2000;35:1061-1066.

11. Antman EM, Braunwald E: Acute myocardial infarction. In Braunwald E, ed: Heart Disease: A Textbook of Cardiovascular Medicine. Fifth Edition. WB Saunders, Philadelphia, 1997, pp. 11841288.

12. Braunwald E: Cardiovascular medicine at the turn of the millennium: Triumphs, concerns, and opportunities. N Engl J Med 1997; 337:1360-1369.

13. Myerburg RJ, Mitrani R, Interian A Jr, Castellanos A: Identification of risk of cardiac arrest and sudden cardiac death in athletes. In Estes NAM, Salem DN, Wang PJ, eds: Sudden Cardiac Death in the Athlete. Futura Publishing Co., Armonk, NY, 1998, pp 25-50.

14. McKenna W, Deanfield J, Faruqui A, England D, Oakley C, Goodwin J: Prognosis in hypertrophic cardiomyopathy: Role of age and clinical, electrocardiographic and hemodynamic features. Am J Cardiol 1981;47:532-538.

15. Myerburg RJ, Kessler KM, Castellanos A: Sudden cardiac death: Epidemiology, transient risk, and intervention assessment. Ann Intern Med 1993;119:1187-1197.

16. Myerburg RJ, Interian A, Mitrani RM, Kessler KM, Castellanos A: Frequency of sudden cardiac death and profiles of risk. Am J Cardiol 1997;80(5B):10F-19F.

17. Rosen MR, Janse MJ, Myerburg RJ: Arrhythmias induced by coronary artery occlusion: What are the electrophysiologic mechanisms? In Hearse D, Manning A, Janse M, eds: Life-Threatening Arrhythmias During Ischemia and Infarction. Raven Press, New York, 1987, pp. 11-47. 
18. Chiang BN, Perlman L, Ostrander LD, Epstein F: Relation of premature systole to coronary heart disease and sudden death in the Tecumseh epidemiologic study. Ann Intern Med 1969;70:11591166.

19. Ruberman W, Weinblatt E, Goldberg JD, Frank CW, Chaudhary BS, Shapiro S: Ventricular premature complexes and sudden death after myocardial infarction. Circulation 1981;64:297-305.

20. Bigger JT, Fleiss JL, Kleiger R, Miller JP, Rolnitzky LM: The relationships among ventricular arrhythmias, left ventricular dysfunction, and mortality in the 2 years after myocardial infarction. Circulation 1984;69:250-258.

21. Ruskin JN, DiMarco JP, Garan H: Out-of-hospital cardiac arrest: Electrophysiologic observations and selection of long-term antiarrhythmic therapy. N Engl J Med 1980;303:607-613.

22. Josephson ME, Horowitz LN, Spielman SC, Greenspan AM: Electrophysiological and hemodynamic studies in patients resuscitated from cardiac arrest. Am J Cardiol 1980;46:948-955.

23. Swerdlow CR, Winkle RA, Mason JW: Determinants of survival in patients with ventricular tachyarrhythmias. N Engl J Med 1983; 308:1436-1442.

24. Liberthson RR, Nagel EL, Hirschman JC, Nussenfeld SR: Prehospital ventricular fibrillation: Prognosis and follow-up course. N Engl J Med 1974;291:317-321.

25. Baum RS, Alvarez H, Cobb LA: Survival after resuscitation from out-of-hospital ventricular fibrillation. Circulation 1974;50:12311235 .

26. Echt DS, Liebson PR, Mitchell LB, Peters RW, Obias-Manno D, Barker AH, Arensberg D, Baker A, Friedman L, Greene HL, et al: Mortality and morbidity in patients receiving encainide, flecainide, or placebo: The Cardiac Arrhythmia Suppression Trial. N Engl J Med 1991;324:781-788.

27. The Cardiac Arrhythmia Suppression Trial II Investigators: Effect of the antiarrhythmic agent moricizine on survival after myocardial infarction. N Engl J Med 1992;27:227-233.

28. Waldo AL, Camm AJ, deRuyter H, Friedman PL, MacNeil DJ, Pauls JF, Pitt B, Pratt CM, Schwartz PJ, Veltri EP, for the SWORD Investigators: Effect of d-sotalol on mortality in patients with left ventricular dysfunction after recent and remote myocardial infarction. The SWORD Investigators. Lancet 1996;348:7-12.

29. Moss AJ, Hall WJ, Cannom DS, Daubert JP, Higgins SL, Klein H, Levine JH, Saksena S, Waldo AL, Wilber D, Brown MW, Heo M, for the Multicenter Automatic Defibrillator Implantation Trial Investigators: Improved survival with an implanted defibrillator in patients with coronary disease at high risk for ventricular arrhythmia. N Engl J Med 1996;335:1933-1940

30. The Antiarrhythmics versus Implantable Defibrillators (AVID) Investigators: A comparison of antiarrhythmic-drug therapy with implantable defibrillators in patients resuscitated from near-fatal ventricular arrhythmias. N Engl J Med 1997;337:1576-1583.

31. Connolly SJ, Gent M, Roberts RS, Dorian P, Roy D, Sheldon RS, Mitchell LB, Green MS, Klein GJ, O'Brien B, Connolly SJ, Gent M, Roberts RS, et al., on behalf of the CIDS Investigators: Canadian Implantable Defibrillator Study (CIDS): A randomized trial of the implantable cardioverter defibrillator against amiodarone. Circulation 2000;101:1297-1302.

32. Buxton AE, Lee KL, Fisher JD, Josephson ME, Prystowsky EN, Hafley G: A randomized study of the prevention of sudden death in patients with coronary artery disease. Multicenter Unsustained Tachycardia Trial Investigators. N Engl J Med 1999;341:18821890.

33. Kuck KH, Cappato R, Siebels J, Ruppel R: Randomized comparison of antiarrhythmic drug therapy with implantable defibrillators in patients resuscitated from cardiac arrest: The Cardiac Arrest Study Hamburg (CASH). Circulation 2000;102:748-754.

34. Klein H, Auricchio A, Reek S, Geller C: New primary prevention trials of sudden cardiac death in patients with left ventricular dysfunction: SCD-HEFT and MADIT-II. Am J Cardiol 1999; 83(5B):91D-97D.

35. Liberthson RR, Nagel EL, Hirschman JC, Nussenfeld SR, Blackbourne BD, Davis JH: Pathophysiologic observations in prehospital ventricular fibrillation and sudden cardiac death. Circulation 1974;49:790-798.

36. Schatzkin A, Cupples LA, Heeren T, Morelock S, Kannel WB:
Sudden death in the Framingham Heart Study. Differences in incidence and risk factors by sex and coronary disease status. Am J Epidemiol 1984;120:888-899.

37. Wilson PW, D' Agostino RB, Levy D, Belanger AM, Silbershatz H, Kannel WB: Prediction of coronary heart disease using risk factor categories. Circulation 1998;97:1837-1847.

38. O' Rourke RA, Brundage BH, Froelicher VF, Greenland P, Grundy SM, Hachamovitch R, Pohost GM, Shaw LJ, Weintraub WS, Winters WL Jr: American College of Cardiology/American Heart Association Expert Consensus Document on electron-beam computed tomography for the diagnosis and prognosis of coronary artery disease. J Am Coll Cardiol 2000;36:326-340.

39. Willich SN, Maclure M, Mittleman M, Arntz HR, Muller JE: Sudden cardiac death. Support for a role of triggering in causation. Circulation 1993;87:1442-1450.

40. Muller JE, Abela GS, Nesto RW, Tofler GH: Triggers, acute risk factors and vulnerable plaques: The lexicon of a new frontier. J Am Coll Cardiol 1994;23:809-813.

41. Leor J, Poole WK, Kloner RA: Sudden cardiac death triggered by an earthquake. N Engl J Med 1996;334:413-419.

42. Bigger JT Jr, Fleiss JL, Steinman RC, Rolnitzky LM, Kleiger RE, Rottman JN: Frequency domain measures of heart period variability and mortality after myocardial infarction. Circulation 1992;85: 164-171.

43. Hartikainen JEK, Malik M, Staunton A, Poloniecki J, Camm AJ: Distinction between arrhythmic and nonarrhythmic death after acute myocardial infarction based on heart rate variability, signalaveraged electrocardiogram, ventricular arrhythmias and left ventricular ejection fraction. J Am Coll Cardiol 1996;28:296-304.

44. Huikuri HV, Castellanos A, Myerburg RJ: Predicting and preventing sudden arrhythmic death: Successes, failures, and opportunities. N Engl J Med (Submitted).

45. La Rovere MT, Bigger JT Jr, Marcus FI, Mortara A, Schwartz PJ: Baroreflex sensitivity and heart-rate variability in prediction of total cardiac mortality after myocardial infarction. ATRAMI (Autonomic Tone and Reflexes After Myocardial Infarction) Investigators. Lancet 1998;351:478-484.

46. Rosenbaum D, Albrecht P, Cohen RJ: Predicting sudden cardiac death from $\mathrm{T}$ wave alternans of the surface electrocardiogram: Promise and pitfalls. J Cardiovasc Electrophysiol 1996;7:10951111.

47. Klingenheben T, Zabel M, D' Agostino RB, Cohen RJ, Hohnloser $\mathrm{SH}$ : Predictive value of T-wave alternans for arrhythmic events in patients with congestive heart failure. Lancet 2000;356:651-652.

48. Zabel M, Klingenheben T, Franz MR, Hohnloser SH: Assessment of QT dispersion for prediction of mortality or arrhythmic events after myocardial infarction. Results of a prospective, long-term follow-up study. Circulation 1998;97:2543-2550.

49. Ross R: Atherosclerosis: An inflammatory disease? N Engl J Med 1999;340:115-126.

50. Ridker PM, Cushman M, Stampfer MJ, Tracy RP, Hennekens CH: Inflammation, aspirin, and the risk of cardiovascular disease in apparently healthy men. N Engl J Med 1997;336:973-979 (Published erratum: N Engl J Med 1997;337:356).

51. Ridker PM, Glynn RJ, Hennekens CH: C-reactive protein adds to the predictive value of total and HDL cholesterol in determining risk of first myocardial infarction. Circulation 1998;97:2007-2011.

52. Ridker PM, Hennekens CH, Buring JE, Rifai N: C-reactive protein and other markers of inflammation in the prediction of cardiovascular disease in women. N Engl J Med 2000;342:836-843.

53. Kuller LH, Tracy RP, Shaten J, Meilahn EN: Reaction of C-reactive protein and coronary heart disease in the MRFIT nested case-control study. Multiple Risk Factor Intervention Trial. Am J Epidemiol 1996;144:537-547.

54. Koenig W, Sund M, Frohlich M, Fischer HG, Lowel H, Doring A, Hutchinson WL, Pepys MB: C-reactive protein, a sensitive marker of inflammation, predicts future risk of coronary heart disease in initially healthy middle-aged men: Results from the MONICA (Monitoring Trends and Determinants in Cardiovascular Disease) Augsburg Cohort Study, 1984 to 1992. Circulation 1999;99:237242.

55. Friedlander Y, Siscovick DS, Weinmann S, Austin MA, Psaty BM, Lemaitre RN, Arbogast P, Raghunathan TE, Cobb LA: Family 
history as a risk factor for primary cardiac arrest. Circulation 1998;97:155-160.

56. Jouven X, Desnos M, Guerot C, Ducimetiere P: Predicting sudden death in the population: The Paris Prospective Study I. Circulation 1999;99:1978-1983.

57. Davies MJ: Anatomic features in victims of sudden coronary death. Coronary artery pathology. Circulation 1992;85(Suppl):I19-I-24.

58. Mehta D, Curwin J, Gomes A, Fuster V: Sudden death in coronary artery disease: Acute ischemia versus myocardial substrate. Circulation 1997;96:3215-3223.

59. Taylor AJ, Burke AP, O' Malley PG, Farb A, Malcom GT, Smialek J, Virmani R: A comparison of the Framingham risk index, coronary artery calcification, and culprit plaque morphology in sudden cardiac death. Circulation 2000;101:1243-1248

60. Goldstein JA, Demetriou D, Grines CL, Pica M, Shoukfeh M, O' Neill WW: Multiple complex coronary plaques in patients with acute myocardial infarction. N Engl J Med 2000;343:915-922.

61. Packard CJ, O' Reilly DS, Caslake MJ, McMahon AD, Docherty G, Ford I, Cooney J, Macphee CH, Suckling KE, Krishna M, Wilkinson FE, Burczak JD, Rumley A, Lowe GD: Lipoproteinassociated phospholipase $\mathrm{A}_{2}$ as an independent predictor of coronary heart disease. N Engl J Med 2000;343:1148-1155.

62. Kubota T, Shimizu W, Kamakura S, Horie M: Hypokalemiainduced long QT syndrome with an underlying novel missense mutation in S4-S5 linker of KCNQ1. J Cardiovasc Electrophysiol 2000;11:1048-1054.

63. Mason JW, for The Electrophysiologic Study versus Electrocardiographic Monitoring Investigators: A comparison of electrophysiologic testing with Holter monitoring to predict antiarrhythmic-drug efficacy for ventricular tachyarrhythmias. N Engl J Med 1993;329:445-451.

64. Myerburg RJ, Mitrani R, Interian A Jr, Castellanos A: Interpretation of outcomes of antiarrhythmic clinical trials. Design features and population impact. Circulation 1998;97:1514-1521.

65. Myerburg RJ, Mitrani RM, Interian AR Jr, Bassett AL, Simmons J, Castellanos A: Life-threatening ventricular arrhythmias: The link between epidemiology and pathophysiology. In Zipes DP, Jalife J, eds: Cardiac Electrophysiology: From Cell to Bedside. Third Edition. WB Saunders, Philadelphia, 2000, pp. 521-530.

66. Laupacis A, Sackett DL, Roberts RS: An assessment of clinically useful measures of the consequences of treatment. N Engl J Med 1988;318:1728-1733.

67. Shepherd J, Cobbe SM, Ford I, Isles CG, Lorimer AR, MacFarlane PW, McKillop JH, Packard CJ: Prevention of coronary heart disease with pravastatin in men with hypercholesterolemia. West of Scotland Coronary Prevention Study Group. N Engl J Med 1995;333:1301-1307.

68. Hallstrom AP, Cobb LA, Ray R: Smoking as a risk factor for recurrence of sudden cardiac arrest. N Engl J Med 1986;314:271275.

69. Boutitie F, Boissel JP, Connolly SJ, Camm AJ, Cairns JA, Julian DG, Gent M, Janse MJ, Dorian P, Frangin G: Amiodarone interaction with beta-blockers: Analysis of the merged EMIAT (European Myocardial Infarct Amiodarone Trial) and CAMIAT (Canadian Amiodarone Myocardial Infarction Trial) databases. The EMIAT and CAMIAT Investigators. Circulation 1999;99:22682275.

70. Julian DG, Camm AJ, Frangin G, Janse MJ, Munoz A, Schwartz PJ, Simon P: Randomized trial of effect of amiodarone on mortality in patients with left-ventricular dysfunction after recent myocardial infarction: EMIAT. European Myocardial Infarct Amiodarone Trial Investigators. Lancet 1997;349:667-674.

71. Cairns JA, Connolly SJ, Roberts R, Gent M: Randomized trial of outcome after myocardial infarction in patients with frequent or repetitive ventricular premature depolarizations: CAMIAT. Canadian Amiodarone Myocardial Infarction Arrhythmia Trial Investigators. Lancet 1997;349:675-682.

72. Liberthson RR, Nagel EL, Hirschman JC, Nussenfeld SR: Prehospital ventricular fibrillation: Prognosis and follow-up course. N Engl J Med 1974;291:317-321.
73. Baum RS, Alvarez H, Cobb LA: Survival after resuscitation from out-of-hospital ventricular fibrillation. Circulation 1974;50:12311235.

74. Eisenberg MS, Copass MK, Hallstrom AP, Blake B, Bergner L, Short FA, Cobb LA: Treatment of out-of-hospital cardiac arrests with rapid defibrillation by emergency medical technicians. N Engl J Med 1980;302:1379-1383.

75. Weaver WD, Compass MK, Buff D, Ray R, Hallstrom AP, Cobb LA: Improved neurologic recovery and survival after early defibrillation. Circulation 1984;69:943-948.

76. Thompson RG, Hallstrom AP, Cobb LA: Bystander-initiated cardiopulmonary resuscitation in the management of ventricular fibrillation. Ann Intern Med 1979;90:737-740.

77. Cobb LA, Weaver WD, Fahrenbrush CE: Community-based interventions for sudden cardiac death: Impact, limitations, and charges. Circulation 1992;85(Suppl I): I-98-I-102.

78. Stults KR, Brown DD, Schug VL, Bean JA: Prehospital defibrillation performed by emergency medical technicians in rural communities. N Engl J Med 1984;310:219-223.

79. Cummins RO, Ornato JP, Thies WH, Pepe PE: Improving survival from sudden cardiac arrest: The "chain of survival" concept: A statement for heart professionals from the Advanced Cardiac Life Support Subcommittee and the Emergency Cardiac Care Committee, American Heart Association. Circulation 1991;83:1832-1847.

80. Lombardi G, Gallagher J, Gennis P: Outcome of out-of-hospital cardiac arrest in New York City: The Pre-Hospital Arrest Survival Evaluation (PHASE) Study. JAMA 1994;271:678-683.

81. Becker LB, Han BH, Meyer PM, Wright FA, Rhodes KV, Smith DW, Barrett J: Racial differences in the incidence of cardiac arrest and subsequent survival. The CPR Chicago Project. N Engl J Med 1993;329:600-606.

82. Auble TE, Menegazzi JJ, Paris PM: Effect of out-of-hospital defibrillation by basic life support providers on cardiac arrest mortality: A meta-analysis. Ann Emerg Med 1995;25:642-648.

83. Stiell IG, Wells GA, Field BJ, Spaite DW, De Maio VJ, Ward R, Munkley DP, Lyver MB, Luinstra LG, Campeau T, Maloney J, Dagnone E: Improved out-of-hospital cardiac arrest survival through the inexpensive optimization of an existing defibrillation program: OPALS study phase II. Ontario Prehospital Advanced Life Support. JAMA 1999;281:1175-1181.

84. White RD, Hankins DG, Bugliosi TF: Seven years' experience with early defibrillation by police and paramedics in an emergency medical services system. Resuscitation 1998;39:145-151.

85. Nichol G, Hallstrom AP, Kerber R, Moss AJ, Ornato JP, Palmer D, Riegel B, Smith S Jr, Weisfeldt ML: American Heart Association report on the second public access defibrillation conference, April 17-19, 1997. Circulation 1998;97:1309-1314.

86. Holmberg M, Holmberg S, Herlitz J: The problem of out-ofhospital cardiac-arrest: Prevalence of sudden death in Europe today. Am J Cardiol 1999;83(5B):88D-90D.

87. Waalewijn RA, de Vos R, Koster RW: Out-of-hospital cardiac arrests in Amsterdam and its surrounding areas: Results from the Amsterdam resuscitation study (ARREST) in "Utstein" style. Resuscitation 1998;38:157-167.

88. Myerburg RJ: Unpublished data.

89. O'Rourke MF, Donaldson E, Geddes JS: An airline cardiac arrest program. Circulation 1997;96:2849-2853.

90. Page RL, Joglar JA, Kowal RC, Zagrodzky JD, Nelson LL, Ramaswamy K, Barbera SJ, Hamdan MH, McKenas DK: Use of automated external defibrillators by a U.S. airline. N Engl J Med 2000;343:1210-1216

91. Lien D, Turner M: Recommendations for patients with chronic respiratory disease considering air travel: A statement from the Canadian Thoracic Society. Can Respir J 1998;5:95-100.

92. DeBehnke DJ, Hilander SJ, Dobler DW, Wickman LL, Swart GL: The hemodynamic and arterial blood gas response to asphyxiation: A canine model of pulseless electrical activity. Resuscitation 1995; 30:169-175.

93. Valenzuela TD, Roe DJ, Nichol G, Clark LL, Spaite DW, Hardman RG: Outcomes of rapid defibrillation by security officers after cardiac arrest in cascinos. N Engl J Med 2000;343:1206-1209. 